\title{
FOREST FIRE TREND AND INFLUENCE OF CLIMATE VARIABILITY IN INDIA: A GEOSPATIAL ANALYSIS AT NATIONAL AND LOCAL SCALE
}

\author{
FIROZ AHMAD*, LAXMI GOPARAJU
}

Vindhyan Ecology and Natural History Foundation, Vindhya Bachao Secretariat, 36/30, Shivpuri Colony, Station Road, Mirzapur-231001, Uttar Pradesh, India; e-mail: adfiroz@yahoo.com

* Author for correspondence

Abstract

Ahmad F., Goparaju L.: Forest fire trend and influence of climate variability in India: a geospatial analysis at national and local scale. Ekológia (Bratislava), Vol. 38, No. 1, p. 49-68, 2019.

Climate change and its severity play an important role in forest fire regime. Analysing the forest fires events becomes a prerequisite for safeguarding the forest from further damage. We have made an assessment of the long-term forest fire events at the district level in India and identified the forest fire hotspot districts. The spatial seasonal (January to June) district wise pattern and forest fire trend were analysed. In the second part of the study area (central part of India), we have evaluated the forest fire events in grid format with respect to the climatic/weather datasets, and the statistical analysis Cramer V coefficient (CVC) was performed to understand its association/ relationship with forest fire events.

The study revealed that Karbi Anglong and North Cachar Hills districts of Assam of India have the highest forest fire percent among all districts equivalent to 3.4 and 3.2\% respectively. Dantewada district of Chhattisgarh and Garhchiroli district of Maharashtra of India occupied 3rd and 4th rank with value 3.1 and $3.0 \%$ respectively. The grid-based evaluation (local scale) revealed that most of the fire equivalent of $80 \%$ was found in the month of March and April. Forest fire frequency of the month of April is spread over $88 \%$ of the grids over the study area. The 11 years average seasonal month-wise (February to June) maximum temperature, wind velocity, relative humidity, and solar radiation were found in the range of (25.9 to 40.6$)$, (1.69 to 2.7$),(0.301$ to 0.736 ) and (14.21 to 22.98) respectively. The percentage increase (in the month of March) of maximum temperature, wind velocity, and solar radiation were 36,39 and $62 \%$ respectively, when compared with the preceding month; whereas, a $60 \%$ decrease to relative humidity that was observed in the same month is usually the major cause of forest fire events in the month of March onwards.

The evaluation of Cramer V coefficient (CVC) values of rainfall, relative humidity, potential evapotranspiration, maximum temperature, wind velocity, and solar radiation were in decreasing order and in the range of 0.778 to 0.293 . The highest value of rainfall $(0.778)$ showed its strongest association with the forest fire events. In the month of June, these areas receive adequate rainfall, which leads to an increase in the soil moisture and a reduction in forest fuel burning capacity by absorbing the moisture and it is a strong reason for less forest fire events during this month. Geospatial technology provides an opportunity to evaluate large datasets over various spatial and temporal scales and help in decision making/formulating various policies.

Key words: forest fire events, forest fire hotspot, meteorological and climatic data, Cramer's V coefficient, India. 


\section{Introduction}

Fire regimes (frequency, intensity, size, pattern, season, and severity) are important contributors in many ecosystems (Bowman et al., 2009; Bond, Keeley, 2005; Gill, 1975), which can change the structure and function of forest landscapes (Mouillot et al., 2002; McKenzie et al., 2004). The climate of a region plays a vital role in regulating the forest fire regimes (Harrison et al., 2010). Climate is one of the most influential factors that decides the vegetation patterns globally and has a significant role in distribution, structure, composition, and ecology of forests (Kirschbaum et al., 1996). Climate variables interact between themselves and with vegetation (Flannigan, Harrington, 1988). Fire activity mostly depends on four factors: fuels load accumulation, local climate/weather condition (i.e., dry, hot, and/or windy periods), source of ignition and people activity (Bond, van Wilgen, 1996; Flannigan et al., 2005; Moritz et al., 2005; Bradstock, 2010).

Although the amount of fuel/ fuel load, its continuity, and fuel distribution pattern (vertical and horizontal) within the forest affect fire activity (Finney, 2001), fuel moisture by and large determines whether fuels can sustain or withhold ignition (Littell et al., 2009), and therefore, it determines its spread (Blackmarr, 1972; Wotton et al., 2010), and these parameters have been found to be an important deciding factor in the amount of area burned (Flannigan et al., 2005). Fires need fuel to burn, heat to ignite and oxygen to feed to carry out their chemical reaction. Weather condition and severity plays a key role in determining all of these necessary conditions to start and spread a forest fire and making fuel available with the percent of moisture content in forest ecosystem (Swetnam, Betancourt, 1998; Littell et al., 2009). A long period without rain leads to drought, which dries out the existing vegetation, making it easier to burn and thus becomes a better fuel source of fire (Pausas, Fernandez-Munoz, 2012). High solar radiation, and thus, high maximum temperature during the summer makes the humidity low by enhancing the evapotranspiration and makes the forest prone to fire (Vicente-Serrano et al., 2010). Winds play a crucial role in starting and spreading a fire (Song, Lee, 2017) by manoeuvring the flames of the initial spark and it provides fresh oxygen so that it can also stir the fire to the new areas in the potential fuel sites.

Some long-term/short-term studies conducted in the past revealed that fire activities have a strong relationship with climate of a region (Krawchuk, Moritz, 2011; Littell et al., 2009; Westerling et al., 2003), whereas seasonal trends in maximum temperature, precipitation, and drought severity (Wells et al., 2004) is a major player in wildfire frequency and the extent of destruction. Forest fires and its intensity have a unique relationship to global warming. The increase in the frequency of wildfires will lead to an increase in global warming (Brown et al., 2004; Running, 2006). Various studies show that global warming increases the temperature (Hansen et al., 2010) especially during summer and this phenomenon increased the weather severity (Sinha Ray, De, 2003) during the fire season by increasing temperature, decreasing relative humidity, increasing evapotranspiration and so on. These all-weather activities increase the fuel's load burning capability, which leads to an increase in the forest fire season span (Vorobyov, 2004) and its severity. The rainfall deficit of preceding year creates a drought-like condition, which further deteriorates the overall forest fire situation. In contrast, forest fire is also contributing to global warming by burning carbon-storing vegetation adding a huge amount of carbon dioxide to the atmosphere (Reddy et al., 2017). 
The forest fire has some positive impact on ecosystem (http://www.positivenegativeeffects.com/wildfires), whereas in most of the cases, it destroys the natural vegetation and reduces the forest cover (Roy, 2003); leads to loss of valuable timber resources (Rodriguezy Silva et al., 2012); destroys the wildlife habitat (Engstrom, 2010) and leads to reduction of wild life species; effects the micro climate, degrades the soil and water catchment areas (Ferreira et al., 2008); causes loss of biodiversity (Secretariat of the convention on biological diversity, 2001) of forest; enhances the air and haze pollution (Srivastava, Singh, 2003; Vadrevu et al., 2011) in atmosphere that can degrade air quality (Riebau, Fox, 2001), leads to vegetation succession and alters the nutrient and global carbon cycles (Kutiel, Inbar, 1993; Capitanio, Carcaillet, 2008); steers the climate change (Ramanathan et al., 2005; Crutzen, Andreae, 1990), leads to global warming; and very adversely affects the socioeconomic condition of the poor inhabitant community/villagers/tribal people, whose life revolves around forests for livelihoods (Aggarwal et al., 2009).

India is one of the mega-biodiversity countries of the world, where forests occupy more than one-fifth of the geographical area. There are nearly 173,000 villages classified as forest villages in India largely occupied by ethnic communities - mostly the tribal people that fully depend on forest resources (Kishwan et al., 2009) and generate revenue for the government by collecting the Minor Forest Products.

Several studies have been carried out in the developed countries regarding forest fire events and their relationship to various environmental parameters. Wotton et al., 2010 studied the fire events and climate/weather parameter in Canada and predicted an increase in fire occurrence of $25 \%$ by 2030 and $75 \%$ by the end of the 21 st century due to the impact of climate change. Tian et al. (2012) studied the climate change variation and impact on forest fire events in China. They used temperature and precipitation of the study area in the baseline period and suggested that the potential burned areas would increase in future due to climate change. Pinol et al. (1998) conducted a study in Europe between the period 1941-1994, which revealed that the fire hazard and risk show an increasing trend and further concluded that climate warming will lead to an increase in a number of wildfires over this area. Tapper et al., 1993 studied the impact of meteorological parameters, such as temperature, relative humidity, wind speed and preceding rainfall when combined with fuel characteristics for fire risks modelling. The study of Krusel et al., 1993 in southern Australia suggested that mean maximum daily temperature and maximum relative humidity are good parameters to predict high fire activities. Antonovsky et al. (1989) study revealed that the chance of fire is strongly correlated to the mean air temperature, total rainfall and the maximum period between two successive rains over the fire season.

Forest fires are adequately studied for risk analysis (Belgherb et al., 2018), to predict the fire damage using FORKOME model (Kozak et al., 2014) and for analysing the soil property due to the fire severity (Šimanský, 2015). Reddy et al. (2017) evaluated the total burnt area extent and $\mathrm{CO}_{2}$ emissions for the whole country India. Giriraj et al. (2010) identified the high fireprone zones. Vadrevu et al. (2008) analysed the spatial patterns on fire events across diversified geographical, vegetation and topographic gradients. Vadrevu et al. (2013) analysed the various fire regimes over the various diverse geographical regions of India. Ahmad and Goparaju (2017) identified the forest fire hotspot districts at the local level. Ahmad et al. (2017) evalu- 
ated the forest fire points and delineated the forest fire hotspot area. The relationship of forest fire events with climate parameter utilizing the Cramer's V coefficient (CVC).

There are no comprehensive studies for forest fire regime analysis and its relationship with respect to various climatic and weather parameter of India, which creates a lacuna in policy implementation. The present study has utilized the nine years' forest fire data for India (point data of forest fire location) and analysed it in the GIS domain towards visualization and evaluating the spatial/temporal dimension of fire pattern district wise and its monthly trend over the fire season. We have also evaluated the forest fire events with grid spacing 0.3 $\mathrm{x} 0.3^{\circ}$ with climate datasets in the second part of the study area to understand their relationship.

The objectives of the present study are as follows:

1. The analysis aims to manifest forest fire hotspot district of India at the national scale and to evaluate the spatial variation (seasonal) district wise and its trend.

2. To analyse the forest fire events using the grids at a local scale to examine its distribution/variation with respect to the meteorological datasets and to examine the association/relationship of these based on the statistical analysis 'Cramer V coefficient' (CVC).

\section{Material and methods}

Study area

The study area was the country India, with the total geographical are equivalent to $3,287,263 \mathrm{~km}^{2}$ and falls between $6^{\circ} 44^{\prime} \mathrm{N}$ to $35^{\circ} 30^{\prime} \mathrm{N}$ latitude and $68^{\circ} 07^{\prime} \mathrm{E}$ to $97^{\circ} 25^{\prime} \mathrm{E}$ longitude (Fig. 1). India retains a forest cover of $21.34 \%$ of the total geographical area of the country (FSI, 2015) and these forests are extremely diverse and heterogeneous in nature along the various geographical and climatic gradient. Forest Survey of India (FSI) defined forest as 'all lands, more than one hectare in area, with a tree canopy density of more than 10\%' (FSI, 2009). Champion and Seth, 1968 classified the forest of India into 16 distinct forest types and further into subtype based on criteria such as physiognomy, structure, phenology, function, plant association, flora, climate, topography, soil, and biotic factors. Natural vegetation occupies $29.36 \%$ of total geographical area of India, whereas the predominant forest types, that is, the tropical dry deciduous and tropical moist deciduous, occupy $68 \%$ of the total forest cover of India (Reddy et al., 2015). A large part of India is dominated by tropical dry deciduous forest which shed their leaves by the end of January and the dead leaves and litter further increases the fuel load on the forest floor.

The reason for forest fires are anthropogenic (Joseph et al., 2009) caused accidentally due to negligence and intentionally. The local people clear the land for specific purposes. In tropical dry deciduous forests, the tribal/villagers start clearing the ground for collecting the mahua (Madhuca indica) flower from the end of February, whereas people/contractor deliberately light fire to enhance the flush of tendu (Diospyros melanoxylon) leaves that fetch them more money in the form of revenue. Shifting cultivation, which is largely practiced in the North Eastern states of India by the tribal ethnic groups, are the major reason of forest fire to this region. Decrease in forest area due to shifting cultivation is equivalent to $23.0 \%$ of the total deforestation in India (Manhas et al., 2006).

Winter season in India is roughly from December to February, followed by the summer season from March to May. During summer, it is noticed that the forest fire incidents are high, which coincides with the period of high amounts of fuel load available on the forest floor.

The meteorological parameters and forest fire events are evaluated at the local level. The area is chosen in the central part of India because it is dominated by deciduous forest, tribal population, and frequent fire incidence.

Data pre-processing and analysis

We used the forest fire counts datasets for the year 2008 to 2016 provided by the Forest Survey of India (FSI) as a free download. FSI has been analysing the forest fires events (from the year 2005 onwards) regularly across the 


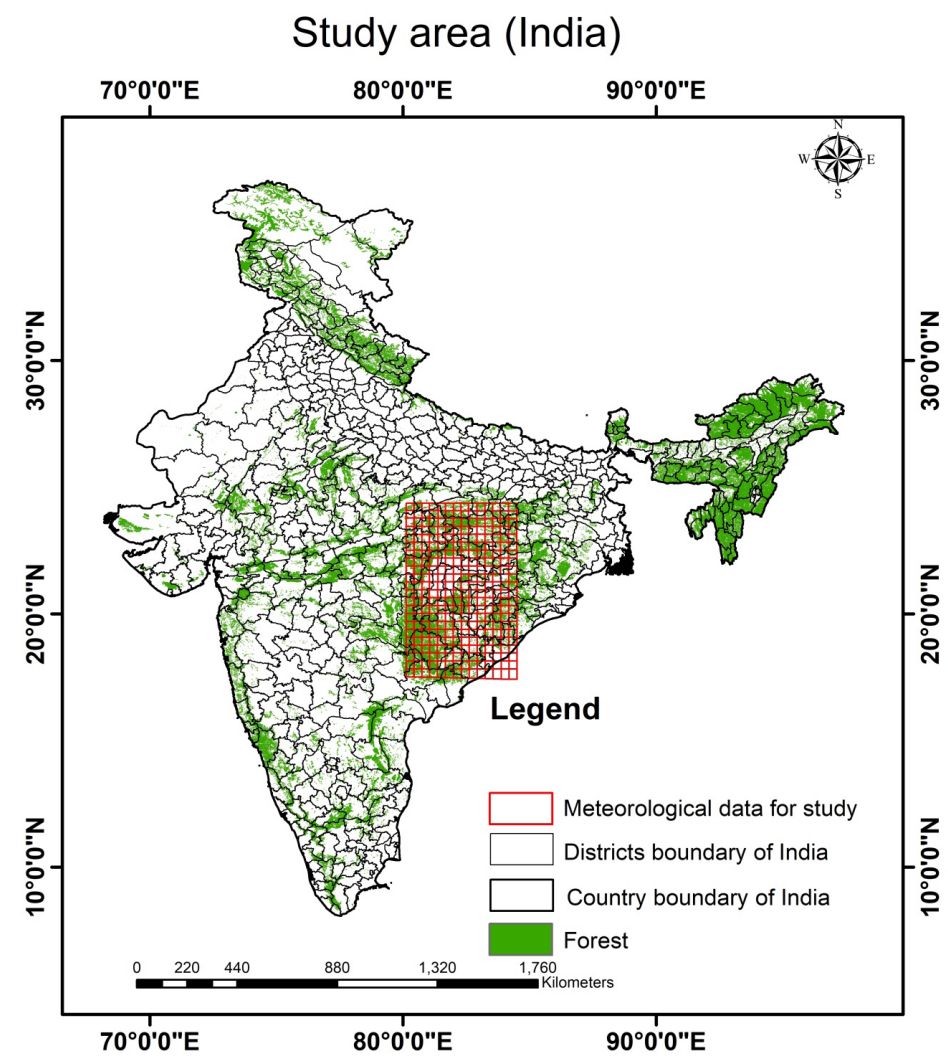

Fig. 1. The location of the study area (India).

country boundary using inputs received from MODIS satellite system by a collaboration with NASA and Geography Department of University of Maryland (http://nidm.gov.in/pdf/pubs/forest\%20fire.pdf). The MODIS based active forest fire point is further masked by FSI using the existing forest cover, which eliminates non-forest fire points. The location wise forest fires points of the latitude and longitude were downloaded (http://fsi.nic.in/forest-fire.php) was in MS-EXCEL format. The ARC/GIS Software was used to export the MS-EXCEL file to point the shapefile. The dates of the forest fires points' shapefile were split into a day, month and year column for further evaluation. In this study, we generated the district wise forest fires hotspots for the whole of India at the national level utilizing all the forest fire datasets (2008-2016). The hotspot area considered in this study was on the basis of the highest forest fire frequency brought into a percentage. The forest fire events of each district were converted into percentage considering the total forest fire events of India as $100 \%$. The forest fire spatial trends (district wise) were also evaluated based on the month wise forest fire data from February to June. We have utilized the Land use and land cover (LULC) data (2005) having $100 \mathrm{~m}$ resolution for India (Roy et al., 2015). LULC map categories representing the forest were merged (except plantation, grassland, and scrubland) for forest mask is given in the Fig. 1.

Climate datasets (maximum temperature, wind velocity, relative humidity and solar radiation) grid wise (11-2004 to 31-7-2014) was downloaded from the website (globalweather.tamu.edu) in one of the forest fires hotspot area, which retains the grid spacing $0.3 \times 0.3^{\circ}$ provided by the National Centers for Environmental Prediction (NCEP) Climate Forecast System Reanalysis (CFSR). 
In this study, the averages of four parameters (maximum temperature, wind velocity, relative humidity, and solar radiation) independently were analysed month wise in the fire season (February to June) and maps were generated based on the 'kriging' interpolation technique. Each grid polygon was evaluated based on the monthly (February to June) forest fire events. We have also downloaded the district wise the monthly (February to June) rainfall, potential evapotranspiration data from 1993 to 2002 from Indian Water Portal 2016 (http://www.indiawaterportal. org/met_data/). The average annual monthly rainfall and potential evapotranspiration data from February to June (fire season) for 10 years were used in this study. Cramer's V coefficient (CVC), as suggested by Liebetrau (1983) for statistical analysis was executed to see the relationship of the climatic parameters with forest fire events.

\section{Result and discussion}

\section{Overall forest fire assessment}

The hotspot district wise map over India is given in Fig. 2. The total forest fire events over India were found approximately 1.95 lakh over the period 2008 to 2016. The highest ten forest fire districts in India were Karbi Anglong (Assam), North Cachar Hills (Assam), Dantewada (Chhattisgarh), Garhchiroli (Maharashtra), Lunglei (Mizoram), Churachandpur (Manipur), Bastar (Chhattisgarh), Mamit (Mizoram), Kandhamal (Orissa) and Tamenglong (Manipur) having the forest fire frequency percent equivalent to $3.4,3.2,3.1,3.0,2.8,2.4,2.2,2.0,1.9$ and $1.6 \%$ respectively, considering the total forest fire percent of country as $100 \%$. These results have their own significance as they were evaluated based on district boundary (an administrative unit), which was the research gap in the past. We have separately evaluated the contribution to forest fire occurrence of northeast region, which are so-called as the 'Seven Sister States.' The forest fire occurrence in the north-eastern states were found to be the highest in Mizoram (27.4\%) followed by Assam (20.4\%), Manipur (16.7\%), Meghalaya (11.7\%), Nagaland (10.1\%), Tripura (8.2\%) and Arunachal Pradesh (5.5\%). Similarly, we have also analysed the central part of the Indian states (Orissa, Chhattisgarh, Madhya Pradesh, Maharashtra, Telangana, and Andhra Pradesh) of India falls in forest fire hotspot, mostly dominated by dense and open dry and moist deciduous forest. The study revealed that Chhattisgarh state had the highest number of forest fire incidences followed by Orissa, Madhya Pradesh, Maharashtra, Andhra Pradesh, and Telangana states.

\section{Forest fire trend}

We have also evaluated the forest fire trend monthly to understand its spatial pattern. The forest fires trend over the month of January, February, March, April, May, and June are given in the Figs 3-8 respectively. The seasonal forest fire frequency \% over the month of February to June at the national level was separately evaluated. The forest fires frequency percent in the months of February, March, April, May, and June are found to be $8,56,28,7$, and $1 \%$ respectively (at the national scale) considering the total forest fire frequency between these periods (February to June) as $100 \%$. Although the forest fire frequency in the month January was very less, while analysing the trend in the same month revealed that the forest fires were found to be the highest in the districts of North-East state of India such as Mon (Nagaland) and Tirap (Arunachal Pradesh) with frequency 116 and 98 respectively. The South Indian state of Telangana 


\section{Forest fire hotspot district map of India}

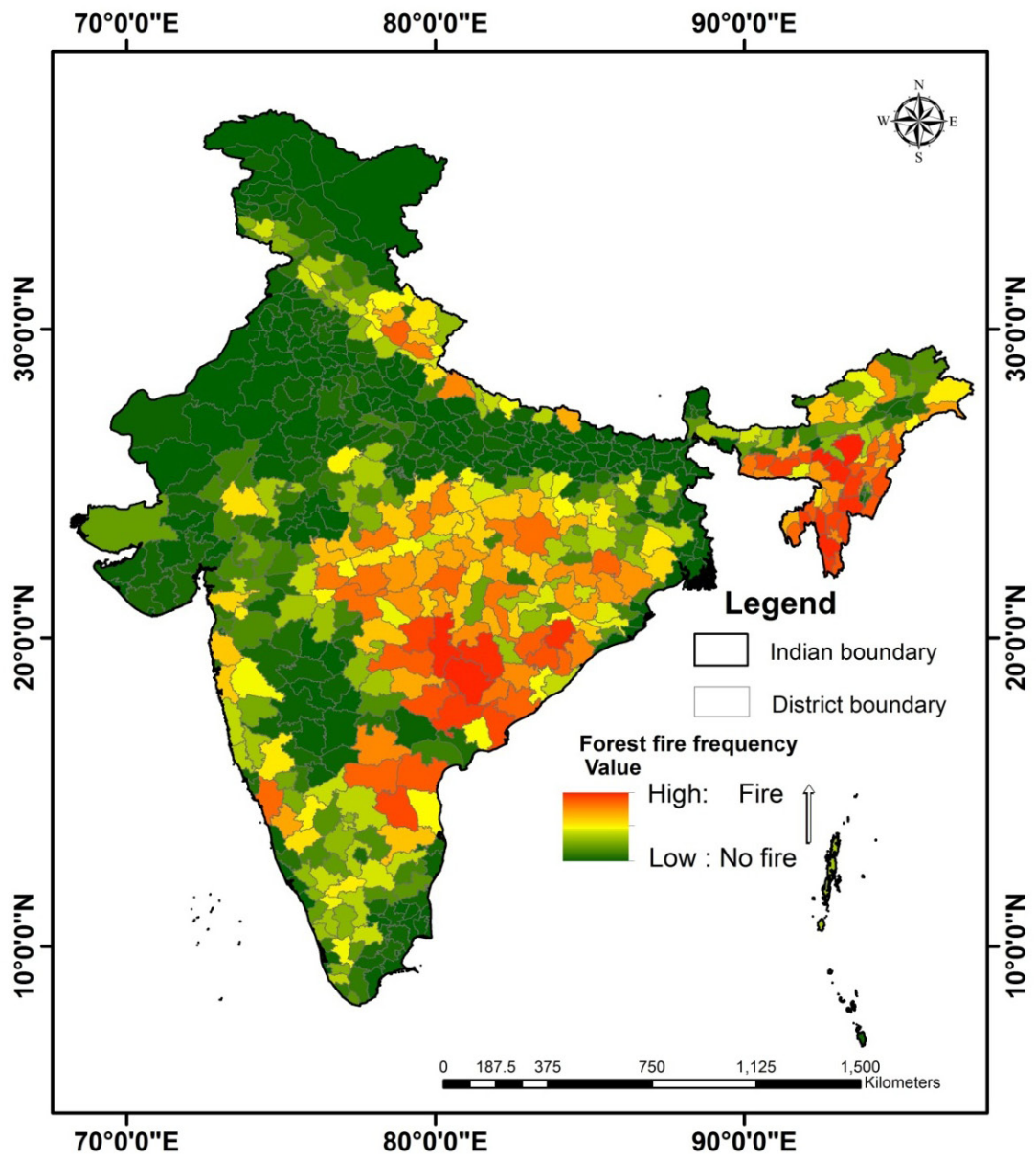

Fig. 2. The forest fire hotspot districts of India.

such as Adilabad district witnessed the frequency value 96 occupied the 3 rd position. Forest fires took a grippe in the southern states of India during the month of February mostly adjoining forest district of state Maharashtra (Garhchiroli), Telangana (Khammam, Warangal), and Chhattisgarh (Dantewada). The forest fire frequency was found to be the highest in the Khammam district, whereas in the other three districts, the forest fire frequencies were in the range of 669 to 602 .

The highest forest fire frequency in the month of March was in the range of 4637 to 1492 , and was observed in the 15 highest forest fire districts. The 13 districts out of these 15 districts were from the northeast states of India. In the southern part of 
India, the forest fire in the month of March were more concentrated in the same districts where the forest fires were the highest in the month February extending further to the new area up to north (Jharkhand state) and northwest (Madhya Pradesh state). In the month of April, the forest fires were found concentrated on the same areas with low forest fire frequency when compared with March, whereas the fires were further intensified in the new areas towards the north side of Pauri Garhwal district of Uttarakhand state of India. In the month of April, the 141 districts of India showed and increasing forest fire frequency trend, whereas 284 districts of India showed a forest fire frequency decreasing trend when compared to the preceding month. The three top districts that showed an increasing trend in the month of April were Pauri Garhwal (Uttarakhand), Karbi Anglong (Assam), and Naini Tal (Uttarakhand) with the difference (increase) fire frequency value as 850,750 , and 504 respectively when compared with the preceding month. Roughly, during the month of May in most of the districts of India, the forest fire frequency showed a decreasing trend except in Jammu and Kashmir, Uttarakhand, Punjab, and Himachal Pradesh, mostly in northern part of India. The forest fire frequency in the month of May roughly reduced to a large extent in the northeast state of India. In the month of June, the forest fire fully disappeared in the northeast because of the active monsoon phenomenon there, whereas it only remained active in the northern states of India because of the late arrival of monsoon. The pre-monsoon showers in the month of June in most parts of India were largely responsible for reducing the forest fire events in this month.

\section{Grid based climatic and fire events data evaluation}

In this study, we have created grids equal to the spacing of climatic point data onto the rectangular area (in the central part of India), where each grid retains the climatic data points falling inside the grid. There were 308 grids with 22 rows and 14 columns. Here, our objective was to study the month wise impact of climate (maximum temperature, solar radiation, relative humidity, and wind velocity) on forest fire events/occurrence depicted in Figs 9, 10, 11, 12 , 13. The grids were evaluated based on the total forest events (2008 to 2016), month wise (from February to June). The forest fire events were depicted with dots. The bigger dots mean higher forest fire events. The green dots mean no forest fires occurrence. Table 1 shows the forest fire events month wise over the rectangular study area at local scale.

This table shows that roughly $80 \%$ of forest fire events are in the month of March and April, whereas the month March retains the highest forest fire events roughly equal to $50 \%$. The evaluation of grid wise forest fire events in the month of February revealed that forest fire frequency was more in the southwestern side. The forest fire frequency in the month of March was spread over $90 \%$ of the grids, whereas out of the total grids, 51 grids (in the count) showed the fire frequency $>=151$ mostly dominated in the southern portion. Similarly, the forest fire frequency in the month of April was spread over $88 \%$ of the grids, whereas out of the total grids, 18 grids and 7 grids (in the count) showed the fire $>=181$ and $>=320$ respectively. A large concentration of fire grids were found in the southern region, concentrated on three pockets shown in Figure 11(a). In May, seven grids (in the count) were showing the 

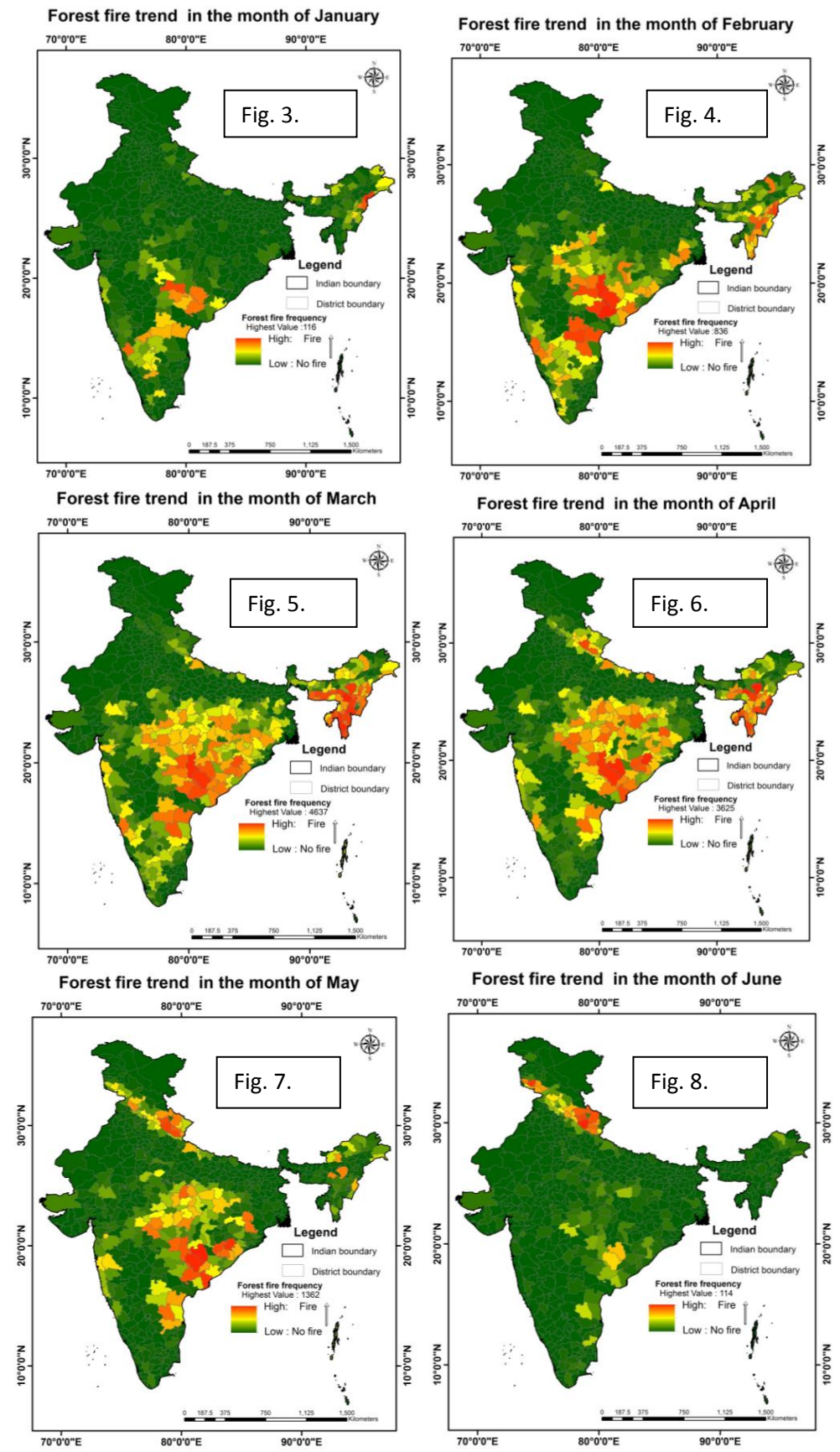

Figs. 3, 4, 5, 6, 7, 8. Month wise forest fire trend from January to June. 
forest fire frequency $>=178$, whereas the large concentration of fire grids were found in the southern/southwest region.

The evaluation of maximum temperature $\left({ }^{\circ} \mathrm{C}\right)$ revealed that the temperature in the month of February was roughly in between 21 to 30, approximately showing high concentration in the central western portion of the grids. The sudden jump in temperature $\left({ }^{\circ} \mathrm{C}\right)$ was observed in the month of March and was found to be roughly in the range of 26 to $41^{\circ} \mathrm{C}$, whereas high temperature was concentrated in the southwestern portion of the grids. The temperature $\left({ }^{\circ} \mathrm{C}\right)$ further showed an increasing trend in the month of April was found in between 28 to $46^{\circ} \mathrm{C}$. The temperature also showed an increasing trend in the month of May and approximately manifested high concentration in the northern region of the grids.

Analysis of relative humidity (fraction) grid wise revealed that the relative humidity in the month of February was roughly in the range of 0.56 to 0.94 . The relative humidity was further decreased in the month of March, whereas the lower value decrease was found the highest from 0.56 to 0.18 (Fig. 10d). The higher value of relative humidity was found the lowest in all the month in April equivalent of 0.79 , whereas it improved in June and was equivalent of 0.83 . The overall relative humidity trend showed that in all the months, the low relative humidity was observed over the northern/ north-western portion of the grids.

Study of wind velocity (meter/second) grid-wise revealed that the wind velocity in the month of February was roughly in between the range of 1.04 to 3.07. The wind velocity further intensified in March and was found in the range of 0.98 to 7.64. The highest wind velocity was observed in the month of April, mostly concentrated in the central western part of the grids equivalent of 7.83 (highest among all months), whereas it reduced in the month of May and found in the ranges of 1.43 to 4.63 .

The solar radiation $\left(\mathrm{MJ} / \mathrm{m}^{\wedge} 2\right)$ grid wise analysis showed that the increasing trend with the highest value from February to May whereas, it reduced slightly in June. The lowest value of solar radiation range was found the highest in March, equivalent of 21.38 among all months (Fig. 10c).

\section{Rainfall and evapotranspiration trend and intensity analysis}

The rainfall shows a strong relationship between the area burned and annual rainfall during summer season (Pausas, 2004). The precipitation and evapotranspiration are important parameters widely used for drought index modelling (Vicente Serrano et al., 2010) and highly useful for forest fire analysis (Wells et al., 2004; Flannigan et al., 2005).

The average monthly rainfall and the potential evapotranspiration over the central part of India during summer season were analysed and depicted in the Figs 14, 15. In this study, we have used 15 districts' data for the evaluation. The rainfall data showed that in the month of June, the areas received good rainfall due to the pre-monsoon and monsoon showers, whereas the

T a b l e 1. Month wise forest fire events.

\begin{tabular}{|l|c|c|c|c|c|}
\hline Month & Feb. & March & April & May & June \\
\hline $\begin{array}{l}\text { Forest fire events } \\
\text { (Frequency) }\end{array}$ & 3614 & 24629 & 16444 & 5640 & 176 \\
\hline Forest fire \% & 7.2 & 48.8 & 32.6 & 11.2 & 0.3 \\
\hline
\end{tabular}




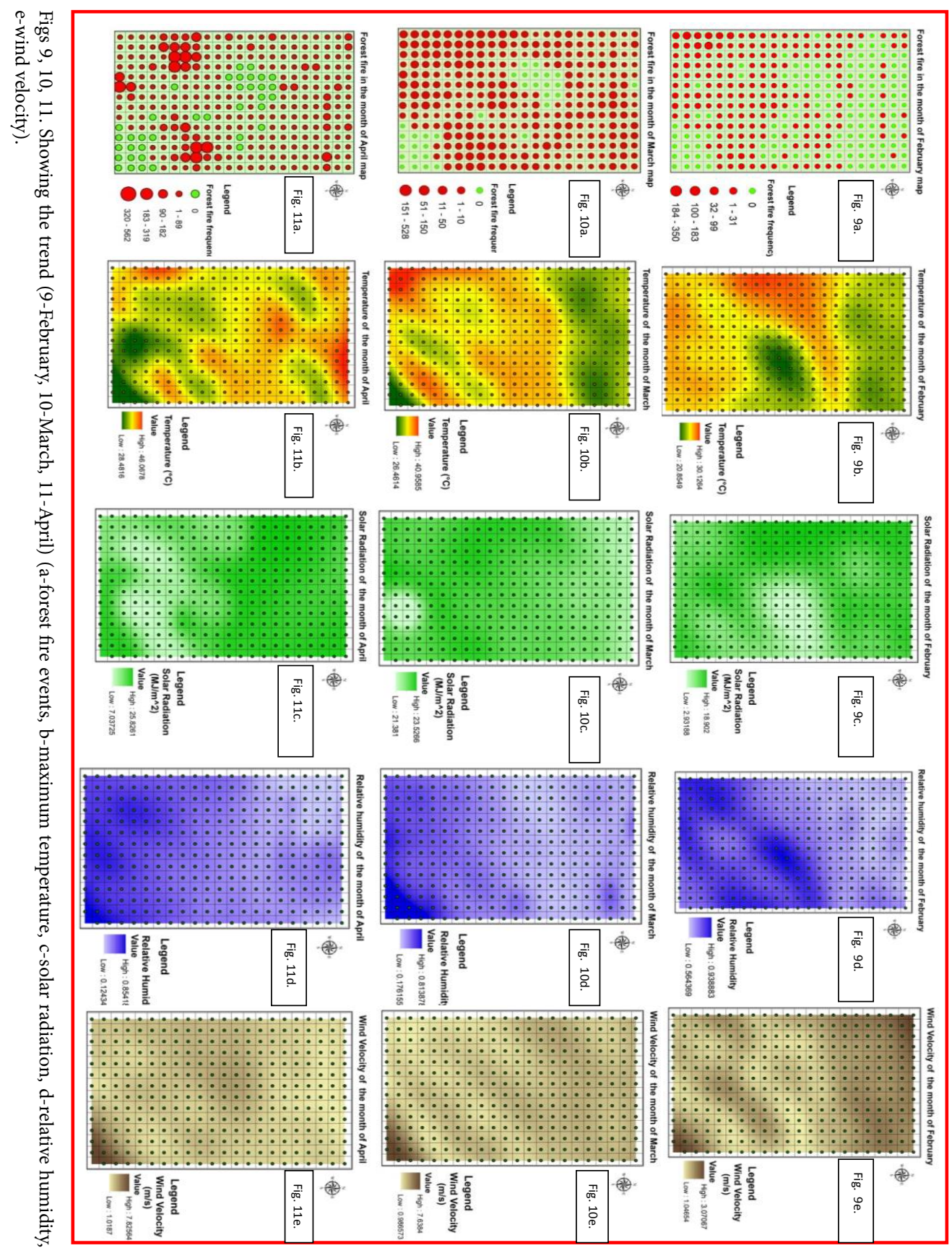




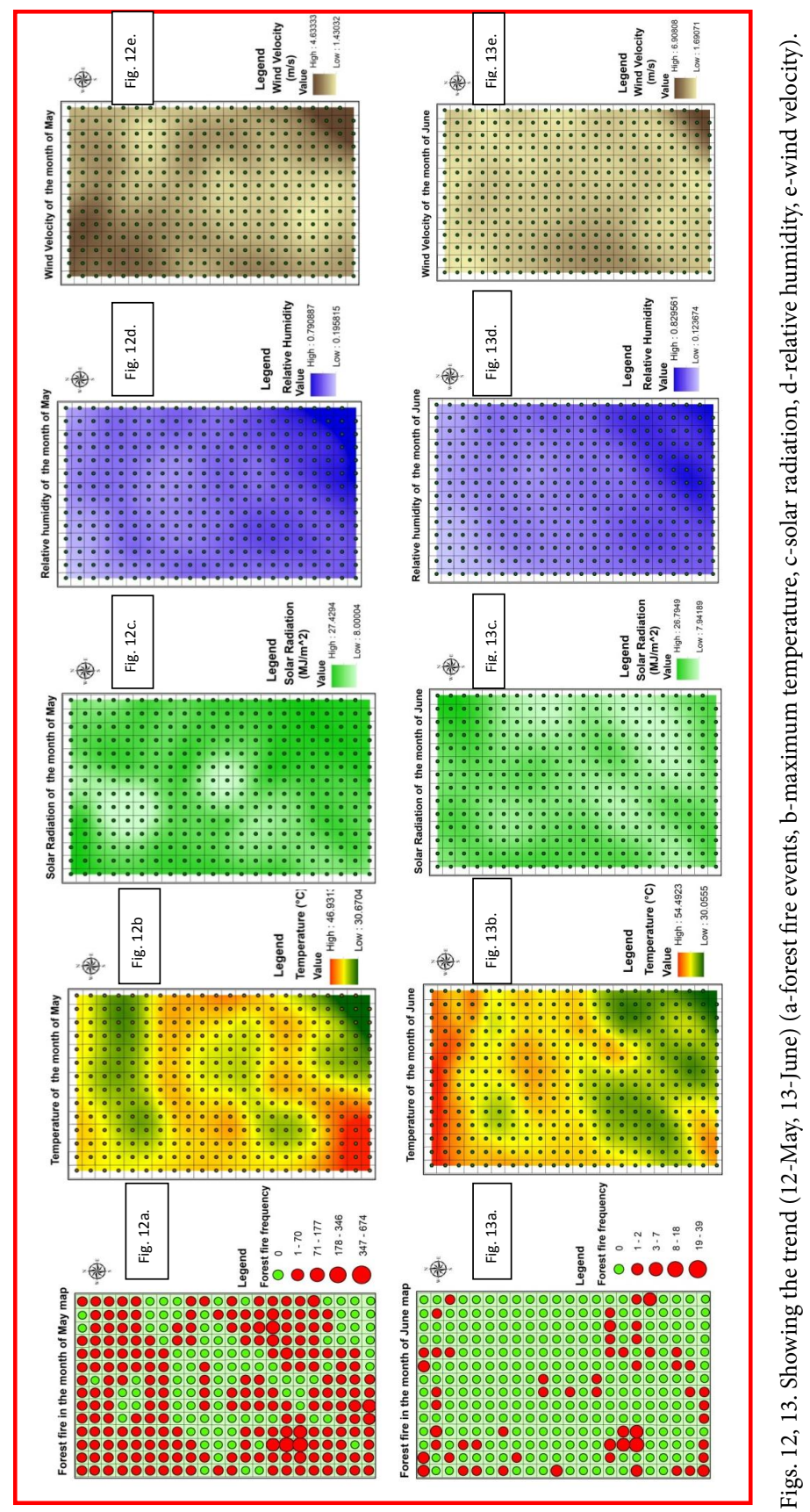


potential evapotranspiration data showed an increasing trend from February to May, but decreased in the month of June. Potential evapotranspiration increase showed the weather severity towards dryness, which leads to an increase in fuel load inflammability available in the forest. Carcaillet, Richard (2000) also highlighted in their study of seasonal precipitation variability over fire occurrences. The month wise data were further evaluated for statistical analysis.

\section{Statistical analysis}

In this case, the objective was to evaluate the month wise climate/weather data for statistical analysis (Crammer's V coefficient) and find out their relation/association with forest fire frequency. The climatic datasets, maximum temperature, wind velocity, relative humidity, and solar radiation were analysed month wise and the averages were calculated. The average monthly basis observations from February to June are recorded in Table 2. The maximum temperature, wind velocity, relative humidity, and solar radiation were found in the range of (25.9 to 40.6$),(1.69$ to 2.7$),(0.301$ to 0.736$)$, and (14.21 to 22.98 ) respectively. The maximum temperature was showing the increasing trend from February to June, whereas the maximum increase of temperature was observed in the month of March with the increased value of $9^{\circ} \mathrm{C}$. A rapid climate change was observed that favoured the forest fire events in the month of March onward. The percentage increase (compared with the month of February) noticed in maximum temperature, wind velocity, and solar radiation were 36,39 and $62 \%$ respectively in the month of March, whereas a $60 \%$ decrease was observed in the relative humidity in the same month. The CVC values of different meteorological parameter (driving factors) are given in Table 3.

Here, the CVC value of rainfall, relative humidity, potential evapotranspiration, maximum temperature, wind velocity, and solar radiation were found in a decreasing order and in the range of 0.293 to 0.778 (Table 3). Except for solar radiation (although it retains the

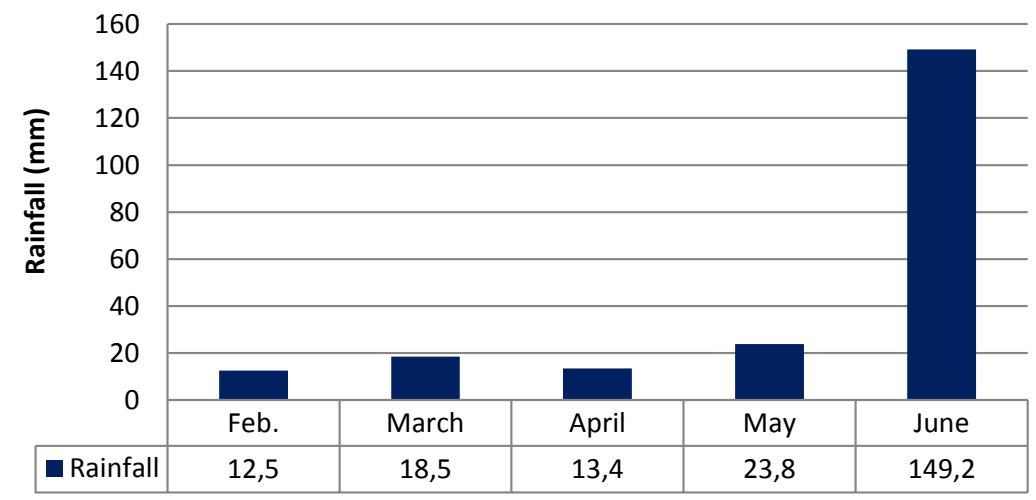

Fig. 14. The Rainfall trend during forest fire season. 


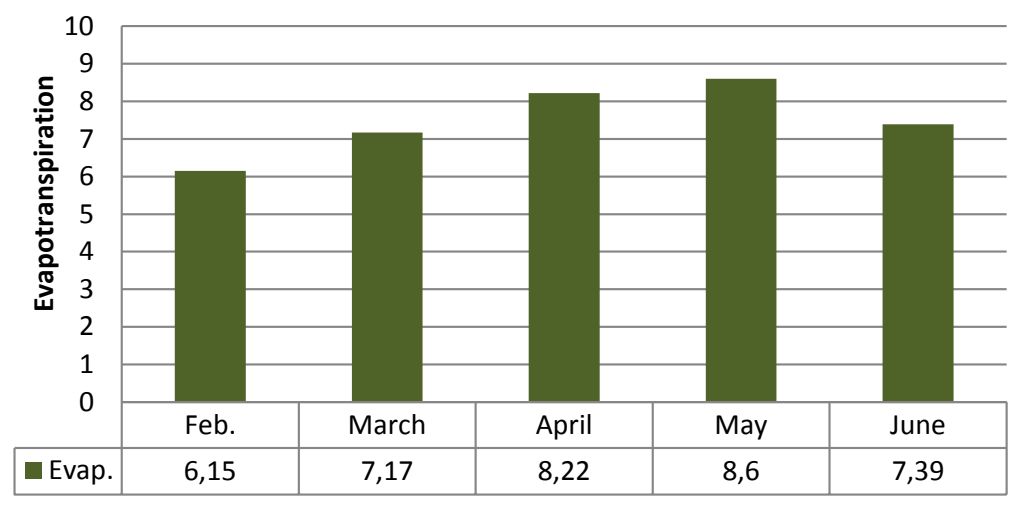

Fig. 15. The potential Evapotranspiration trend during forest fire season.

value roughly 0.3 ), all the other climatic parameter showed strong association with forest fire events. The CVC value of rainfall was found the highest equivalent to 0.78 , which showed its strong association/relationship with fire events. The rainfall significantly increased the soil moisture and reduced forest fuel burning capacity by absorbing moisture in it. Wang et al., 2016 also described the value greater than 0.3 of CVC and shows strong relationships with the driving factor for their study. A similar finding has been observed by Ahmad et al., 2017.

\section{Climate anomalies and its impact}

In recent years, the potential impacts of climate change and variability have been widely discussed and received a lot of attention from the researchers around the globe. Fire and climate have strong linkages (Swetnam, Betancourt, 1990; Marlon et al., 2008; Aldersley et al., 2011), climate-related disruptions to fire activity will occur in many old and new areas. By various research findings, it has been well proved that climate plays a significant role, which decides the fire behaviour (Flannigan et al., 2000; Fried et al., 2004) attributing it to the forest fire events (Stephens, 2005; Westerling et al., 2006) anomalies. Studies conducted by Pinol et al. (1998), Tian et al. (2012), and Wotton et al. (2010) revealed that forest fire events will be more severe in the future.

A study conducted by NASA also revealed that the global temperature increased by roughly $1{ }^{\circ} \mathrm{C}$ in the year 2016, whereas it shows a continuous increasing trend after the year 1978 (https:// climate.nasa.gov). The average temperature increase by approximately $1{ }^{\circ} \mathrm{C}$ will increase the duration of the fire season by $30 \%$ (Vorobyov, 2004). Increase in summer temperature maneuvered by an induced climate change leads to influencing the forest fire regime in a direct or indirect way (Wells et al., 2004). In the above study, it was also observed that the temperature significantly increased in the summer month (April, May).

A warmer climate in summer leads to higher rates of evapotranspiration in the forest ecosystem. These processes, in association with a shifting pattern of precipitation, will affect the spa- 
T a b l e 2. Meteorological average data on monthly basis from February to June.

\begin{tabular}{|l|c|c|c|c|c|}
\hline Average of 11 years $(\mathbf{2 0 0 4}-\mathbf{2 0 1 4})$ & Feb. & March & April & May & June \\
\hline Maximum Temperature $\left({ }^{\circ} \mathrm{C}\right)$ & 25.9 & 35.1 & 39.5 & 40.2 & 40.6 \\
\hline Wind Velocity $(\mathrm{m} / \mathrm{s})$ & 1.69 & 2.35 & 2.21 & 2.26 & 2.7 \\
\hline Relative Humidity $($ fraction$)$ & 0.736 & 0.301 & 0.429 & $0 . .412$ & 0.442 \\
\hline Solar Radiation $\left(\mathrm{MJ} / \mathrm{m}^{\wedge} 2\right)$ & 14.21 & 22.98 & 19.72 & 21.6 & 16.53 \\
\hline
\end{tabular}

T a b l e 3. Crammer's V coefficient (CVC) values of forest fire driving factors.

\begin{tabular}{|l|c|}
\hline Meteorological variable (Driving factors) & Forest fire frequency Crammer's V coefficient (CVC) \\
\hline Maximum Temperature & 0.399 \\
\hline Solar Radiation & 0.293 \\
\hline Wind Velocity & 0.383 \\
\hline Relative Humidity & 0.415 \\
\hline Potential Evapotranspiration & 0.414 \\
\hline Rainfall & 0.778 \\
\hline
\end{tabular}

tial and temporal distribution of soil moisture, relative humidity and increase the probability of droughts. The severity of drought plays a significant role in the wildfire frequency and extent of damage (Wells et al., 2004) and also the increase in forest fire season (Flannigan et al., 2005). Various studies show that India will face climate change in the future. A study conducted by Chaturvedi et al. (2011) on the impact of climate change over India based on an assessment on climate projections. Model scenarios revealed that the many forest dominant states of the central part of India such as Chhattisgarh, Karnataka, and Andhra Pradesh (including Telangana) are projected to undergo a change in forested grids. The study conducted in North East region of India by Jhajharia et al. (2009) suggested that the two parameters, viz. sunshine duration (solar radiation) and wind speed, strongly influenced, which leads to changes in evaporation at various sites, whereas the study by Jain et al. (2013) at the same region showed all four temperature variables, viz. maximum, minimum, and mean temperatures and temperature range had a rising trend. These trends will further enhance the fire frequency and occurrences in the forest fire hotspot area of North East region, which is already more fragile as far as forest fire is concerned. This was also proved in our study.

Dry deciduous forests of India are more vulnerable to forest fire (FAO, 2001). The area of the central part of India are largely occupied by deciduous forest and provide shelter to large population of marginalized ethnic tribes/weaker sections and have integrated linkages to their livelihood seem to be the forest fire hotspots are also experiencing a decreasing trend of rainfall and in number of rainy days (Kumar, Jain, 2011) and need immediate policy intervention to cope with future challenge. These above studies of climatic anomalies over Indian region will lead to an increase in forest fire events in future and are a major policy concern towards its prevention and control. Finally, we can conclude that more studies are required based on participatory and cross-disciplinary approach (Meinke, Stone, 2005) at the national level in India on climate change anomalies and its impact on forest fire events, and its hidden linkage with tribal population, livelihood and 
food security must be addressed adequately by research studies to closely monitor their relationship/impact and suggesting/implementing long-term strategies to reduce its impact on forests.

\section{Conclusion}

This study has analysed the long-term forest fire events at the district level of India and identified the high forest fire districts and its temporal trend. We have also evaluated the relationship between forest fire events and climate datasets supported by statistical analysis based on the values of Crammer's V coefficient (CVC) at the local level. This research revealed that the climate parameters have a strong correlation with forest fire occurrence especially in summer. This was supported by several research findings especially in the developed countries, whereas this is a research interstice in the Indian region in the prevalent climate change scenario. Bowman et al. (2009) rightly said, 'We're most concerned that fire has not been rigorously and adequately incorporated in the climate models.'

In this study, we have found that several districts of India have significantly high forest fire events. Thus, there is an urgent need to formulate and implement the forest fire policy by the Indian government keeping in mind the socio-economic conditions of the local inhabitants. Furthermore, weather forecast and an alarm system should be warranted on a daily basis during forest fire periods. The weather severity and its trend should be sent to respective administrative headquarters, which will significantly help them to take adequate preventive measures to control the extent of its damage.

Our study showed 6 out of 10 highest forest fire districts of India falls on the northeast region. These forest dominated area harbour significantly high percentage of the tribal population and they are facing acute poverty due to diminishing livelihood condition. Shifting cultivations are widely practiced by them due to their very poor socioeconomic status. The government bodies, NGO, and local administration should initiate such programs to enhance the livelihood of the local people practicing shifting cultivation by involving them in forest afforestation, conservation, and protection activity through empowered village forest management committees (VFMCs) on the line of joint forest management (JFM).

The forest fires are significantly high in some of the districts and will continue to increase in future due to climate change. Thus, there is a need of a new division in the forest department, especially in forest fire hotspot areas, headed by a forest officer who will look into all the activities related to fire prevention, control, and its conservation planning and future strategy. There is a need for adequate support of manpower, funds, equipment, and technology to increase the effectiveness for fire prevention and control. Furthermore, the fire awareness and educational activities should be initiated in and around the high forest fire zone/district involving the local community and other groups in a fire management programme and including them as a responsible partner.

Climate plays a significant role in forest fire regime, whereas comprehension of their interaction is very poor in the Indian subcontinent. Thus, there is a need for more future research in the field of a forest fire, climate change and socio-economic linkage of the tribal community that will give better understanding and knowledge. Furthermore, there is a need to develop fire risk predictive models utilizing fire events, meteorological and other dependent parameters in this region, which will work as future research strategies. 
Geospatial technology has enormous capability and can be potentially used in mapping, monitoring of forest health (quantitative and qualitative) and its disturbance. Its vital role cannot be ignored, and thus, should be incorporated in decision making so that appropriate conservation related policy/decisions are taken in time.

\section{Acknowledgements}

The authors are grateful to the Forest survey of India (FSI), DIVA GIS, National Centers for Environmental Prediction (NCEP) for providing free download of various dataset used in the analysis.

\section{References}

Aggarwal, A., Paul, V. \& Das S. (2009). Forest resources: Degradation, livelihoods, and climate change. In D. Datt \& S. Nischal (Eds.), Looking back to change track (pp. 91-108). New Delhi: TERI.

Ahmad, F. \& Goparaju L. (2017). Geospatial assessment of forest fires in Jharkhand (India). Indian Journal of Science and Technology, 10(21), 1-7. DOI: 10.17485/ijst/2017/v10i21/113215.

Ahmad, F., Goparaju, L., Qayum, A. \& Quli S.M.S. (2017). Forest fire trend analysis and effect of environmental parameters: A study in Jharkhand State of India using geospatial technology. World Scientific News, 90, 31-50. www. worldscientificnews.com

Aldersley, A., Murray, S.J. \& Cornell S.E. (2011). Global and regional analysis of climate and human drivers of wildfire. Sci. Total Environ., 409, 3472-3481. DOI: 10.1016/j.scitotenv.2011.05.032.

Antonovsky, M.Ya., Ter-Mikhaelian, M.T. \& Furyaev V.V. (1989). A spatial model of longterm forest fire dynamics and its applications to forests in western Siberia. WP-89-109. Laxenburg: International Institute for Applied Systems Analysis.

Belgherbi, B., Benabdeli, K. \& Mostefai K. (2018). Mapping the risk forest fires in Algeria: Application of the forest of Guetarnia in Western Algeria. Ekológia (Bratislava), 37(3), 289-300. DOI: 10.2478/eko-2018-0022.

Blackmarr, W.H. (1972). Moisture content influences ignitability of slash pine litter. Research Note SE-173. Asheville: U.S. Department of Agriculture, Forest Service, Southeastern Forest Experiment Station.

Bond, W.J. \& van Wilgen B.W. (1996). Fire and plants. London: Chapman and Hall.

Bond, W.J. \& Keeley J.E. (2005). Fire as a global "herbivore": The ecology and evolution of flammable ecosystems. Trends Ecol. Evol., 20, 387-394. DOI: 10.1016/j.tree.2005.04.025.

Bowman, D.M., Balch J.K., Artaxo, P., Bond, W.J., Carlson, J.M., Cochrane, M.A., DAntonio, C.M., DeFries, R.S., Doyle, J.C., Harrison, S.P., Johnston, F.H., Keeley, J.E., Krawchuk, M.A., Kull, Ch.A., Marston, J.B., Moritz, M.A., Prentice, I.C., Roos, Ch.I., Scott, A.C., Swetnam, T.W., van der Werf, G.R. \& Pyne S.J. (2009). Fire in the earth system. Science, 324, 481-484. DOI: $10.1126 /$ science.1163886.

Bradstock, R.A. (2010). A biogeographical model of fire regimes in Australia: current and future implications. Glob. Ecol. Biogeogr., 19, 145-158. DOI: 10.1111/j.1466-8238.2009.00512.x.

Brown, T.J., Hall, B.L. \& Westerling A.L. (2004). The impact of twenty-first century climate change on wildland fire danger in the western United States: an appli-cations perspective. Clim. Change, 62, 365-388. DOI: 10.1023/B:CLIM.0000013680.07783.de.

Capitanio, R. \& Carcaillet C. (2008). Post-fire Mediterranean vegetation dynamics and diversity: A discussion of succession models. For. Ecol. Manag., 255, 431-439. DOI: 10.1016/j.foreco.2007.09.010.

Carcaillet, C. \& Richard P.J.H. (2000). Holocene changes in seasonal precipitation highlighted by fire incidence in eastern Canada. Climate Dynamics, 16(7), 549-559. DOI: 10.1007/s003820000062.

Champion, H. \& Seth S.K. (1968). A revised survey of the forest types of India. Delhi: Manager of Publications.

Chaturvedi, R.K., Gopalakrishnan, R., Jayaraman, M., Bala, G., Joshi, N.V., Sukumar, R. \& Ravindranath N.H. (2011). Impact of climate change on Indian forests: a dynamic vegetation modeling approach. Mitigation and Adaptation Strategies for Global Change, 16(2), 119-142. DOI: 10.1007/s11027-010-9257-7.

Crutzen, P.J. \& Andreae M.O. (1990). Biomass burning in the tropics: impact on atmospheric chemistry and biogeochemical cycles. Science, 250(4988), 1669-1678. DOI: 10.1126/science.250.4988.1669.

Engstrom, R.T. (2010). First-order fire effects on animals: review and recommendations. Fire Ecology, 6(1), 115-130. DOI: 10.4996/fireecology.0601115.

FAO (2001). Global forest fire assessment 1990-2000. Rome: FAO (Forest Resources Assessment). 
Ferreira, A.J.D., Coelho, C.O.A., Ritsema, C.J., Boulet, A.K. \& Keizer J.J. (2008). Soil and water degradation processes in burned areas: Lessons learned from a nested approach. Catena, 74, 273-285. DOI: 10.1016/j.catena.2008.05.007.

Finney, M.A. (2001). Design of regular landscape fuel treatment patterns for modifying fire growth and behavior. For. Sci., 47, 219-229. DOI: 10.1093/forestscience/47.2.219.

Flannigan, M.D. \& Harrington J.B. (1988). A study of the relation of meteorological variables to monthly provincial area burned by wildfire in Canada 1953-1980. Journal of Applied Meteorology, 27, 441-452. https://www.jstor.org/stable/26183591.

Flannigan, M.D., Stocks, B.J. \& Wotton B.M. (2000). Climate change and forest fires. Sci. Total Environ., 262(3), $221-229$. DOI: 10.1016/S0048-9697(00)00524-6.

Flannigan, M.D., Logan, K.A., Amiro, B.D., Skinner, W.R. \& Stocks B.J. (2005). Future area burned in Canada. Clim. Change, 72, 1-16. DOI: 10.1007/s10584-005-5935-y.

Fried, J.S., Torn, M.S. \& Mills E. (2004) The impact of climate change on wildfire severity: a regional forecast for northern California. Clim. Change, 64(1-2), 169-191. DOI: 10.1023/B:CLIM.0000024667.89579.ed.

FSI (2009). State of Forest Report (1987-2007). Dehra Dun: Forest Survey of India, Ministry of Environment and Forests.

FSI (2015). http://fsi.nic.in/isfr-2015/isfr-2015-executive-summary.pdf (accessed on 15th November 2017).

Gill, A.M. (1975). Fire and the Australian flora: A review. Aust. For., 38, 4-25. DOI: 10.1080/00049158.1975.10675618.

Giriraj, A., Babar, S., Jentsch, A., Sudhakar, S. \& Murthy M.S.R. (2010 Tracking fires in India using Advanced Along Track Scanning Radiometer (A)ATSR data. Remote Sensing, 2, 591-610. DOI: 10.3390/rs2020591.

Hansen, J., Ruedy, R., Sato, M. \& Lo K. (2010). Global surface temperature change. Reviews of Geophysics, 48, RG4004. DOI: 10.1029/2010RG000345.

Harrison, S., Marlon, J. \& Bartlein P. (2010). Fire in the earth system. In J. Dodson (Ed.), Changing climates, earth systems and society (pp. 21-48). Dordrecht: Springer. DOI: 10.1007/978-90-481-8716-4.

Jain, S.K., Kumar, V. \& Saharia M. (2013). Analysis of rainfall and temperature trends in northeast India. International Journal of Climatology, 33(4), 968-978. DOI: 10.1002/joc.3483.

Jhajharia, D., Shrivastava, S.K., Sarkar, D. \& Sarkar S. (2009). Temporal characteristics of pan evaporation trends under the humid conditions of northeast India. Agric. For. Meteorol., 149, 763-770. DOI: 10.1016/j.agrformet.2008.10.024.

Joseph, S., Anitha, K. \& Murthy M.S.R. (2009). Forest fire in India: a review of the knowledge base. J. For. Res., 14, $127-134$. DOI: $10.1007 / \mathrm{s} 10310-009-0116-\mathrm{x}$.

Kirschbaum, M. \& Fischlin A. (1996). Climate change impacts on forests. In R. Watson, M.C. Zinyowera \& R.H. Moss (Eds.), Climate change 1995 - Impacts, adaptations and mitigation of climate change: scientific-technical analysis (pp. 95-129). Cambridge: Cambridge University Press.

Kishwan, J., Pandey, R. \& Dadhwal V.K. (2009). India’s forest and tree cover: contributions as a carbon sink. Technical paper No 130 by Indian Council of Forestry Research and Education, ICFRE Bl-23. http://www.envfor.nic.in/mef/ Technical_Paper.pdf

Kozak, I., Węgiel, A., Strzeliński, P., Frąk, R., Stępień, A., Kociuba, P. \& Kozak H. (2014). FORKOME model application for prognosis of forest fires. Ekológia (Bratislava), 33(4), 391-400. DOI: 10.2478/eko-2014-0035.

Krawchuk, M.A. \& Moritz M.A (2011). Constraints on global fire activity vary across a resource gradient. Ecology, 92(1), 121-132. DOI: 10.1890/09-1843.1.

Krusel, N., Packham, D. \& Tapper N.J. (1993). Wildfire activity in the malee shrubland of Victoria, Australia. Int. J. Wildland Fire, 3(4), 217-227. DOI: 10.1071/WF9930217.

Kumar, V. \& Jain S.K. (2011). Trends in rainfall amount and number of rainy days in river basins of India (1951-2004). Hydrology Research, 42(4), 290-306. DOI: 10.2166/nh.2011.067.

Kutiel, P. \& Inbar M. (1993). Fire impacts on soil nutrients and soil erosion in a Mediterranean pine forest plantation. Catena, 20, 129-139. DOI: 10.1016/0341-8162(93)90033-L.

Liebetrau, A.M. (1983). Measures of association. Newbury Park: Sage Publications.

Littell, J.S., McKenzie, D. L., Peterson, D.L. \& Westerling A.L. (2009). Climate and wildfire area burned in western U.S. ecoprovinces, 1916-2003. Ecol. Appl., 19(4), 1003-1021. DOI: 10.1890/07-1183.1.

Manhas, R.K., Negi. J.D.S., Kumar, R. \& Chauhan P.S. (2006). Temporal assessment of growing stock, biomass and carbon stock of Indian forests. Clim. Change, 74, 191-221. DOI: 10.1007/s10584-005-9011-4.

Marlon, J.R., Bartlein, P.J., Carcaillet, C., Gavin, D.G., Harrison, S.P., Higuera, P.E., Joos, F., Power, M.J. \& Prentice I.C. (2008). Climate and human influences on global biomass burning over the past two millennia. Nature Geoscience, 1, 697-702.

McKenzie, D., Gedalof, Z., Peterson, D.L. \& Mote P. (2004). Climatic change, wildfire, and conservation. Conserv. Biol., 18(4), 890-902. DOI: 10.1111/j.1523-1739.2004.00492.x. 
Meinke, H. \& Stone R.C. (2005). Seasonal and inter-annual climate forecasting: The new tool for increasing preparedness to climate variability and change in agricultural planning and operations. Clim. Change, 70, 221-253. DOI: 10.1007/s10584-005-5948-6.

Moritz, M.A., Morais, M.E., Summerell, L.A., Carlson, J.M. \& Doyle J. (2005). Wildfires, complexity, and highly optimized tolerance. Proc. Natl. Acad. Sci. USA, 102(50), 17912-17917. DOI: 10.1073/pnas.0508985102.

Mouillot, F., Rambal, S. \& Joffre R. (2002). Simulating climate change impacts on fire frequency and vegetation dynamics in a Mediterranean-type ecosystem. Global Change Biology, 8(5), 423-437. DOI: 10.1046/j.13652486.2002.00494.x.

Pausas, J.G. (2004). Changes in fire and climate in the eastern Iberian Peninsula (Mediterranean Basin). Clim. Change, 63(3), 337-350. DOI: 10.1023/B:CLIM.0000018508.94901.9c.

Pausas, J.G. \& Fernández-Muñoz S. (2012). Fire regime changes in the western Mediterranean Basin: From fuel-limited to drought-driven fire regime. Clim. Change, 110, 215-226. DOI: 10.1007/s10584-011-0060-6.

Pinol, J., Terradas, J. \& Lloret F. (1998). Climate warming, wildfire hazard, and wildfire occurrence in coastal eastern Spain. Clim. Change, 38, 345-357. DOI: 10.1023/A:1005316632105.

Ramanathan, V., Chung, C., Kim, D., Bettge, T., Buja, L., Kiehl, J.T., Washington, W.M., Fu, Q., Sikka, D.R. \& Wild M. (2005). Atmospheric brown clouds: impacts on South Asian climate and hydrological cycle. Proc. Natl. Acad. Sci. USA, 102(15), 5326-5333. DOI: 10.1073/pnas.0500656102.

Reddy, C.S., Jha, C.S., Diwakar, P.G. \& Dadhwal V.K. (2015). Nationwide classification of forest types of India using remote sensing and GIS. Environ. Monit. Assess., 187(12), 777. DOI: 10.1007/s10661-015-4990-8.

Reddy, C.S., Alekhya, V.V.L. P., Saranya, K.R.L., Athira, K., Jha, C.S., Diwakar, P.G. \& Dadhwal V.K. (2017). Monitoring of fire incidences in vegetation types and Protected Areas of India: Implications on carbon emissions. Journal of Earth System Science, 126, 11. DOI: 10.1007/s12040-016-0791-x.

Riebau, A.R. \& Fox D. (2001). The new smoke management. Int. J. Wildland Fire, 10, 415-427. DOI: 10.1071/WF01039.

Rodriguez y Silva, F., Molina, J.R., González-Cabán, A. \& Machuca H.M.A. (2012). Economic vulnerability of timber resources to forest fires. J. Environ. Manag., 100, 16-21. DOI: 10.1016/j.jenvman.2011.12.026.

Roy, P.S. (2003). Forest fire and degradation assessment using satellite remote sensing and geographic information system fire and degradation assessment using satellite remote sensing and geographic information system. In M.V.K. Sivakumar, P.S. Roy, K. Harmsen \& S.K. Saha (Eds.), Satellite Remote Sensing and GIS Applications in Agricultural Meteorology (pp. 361-400). Proceedings of a Training Workshop, 7-11 July 2003 in Dehra Dun, India.

Roy, P.S., Roy, A., Joshi, P.K., Kale, M.P., Srivastava, V.K., Srivastava, S.K., Dwevidi, R.S., Joshi, C., Behera, M.D., Meiyappan, P., Sharma, Y., Jain, A.K., Singh, J.S., Palchowdhuri, Y., Ramachandran, R.M., Pinjarla, B., Chakravarthi, V., Babu, N., Gowsalya, M.S., Thiruvengadam, P., Kotteeswaran, M., Priya, V., Yelishetty, K.M.V.N., Maithani, S., Talukdar, G., Mondal, I., Rajan, K.S:, Narendra, P.S., Biswal, S., Chakraborty, A., Padalia, H., Chavan, M., Pardeshi, S.N., Chaudhari, S.A., Anand, A., Vyas, A., Reddy, M.K., Ramalingam, M., Manonmani, R., Behera, P., Das, P., Tripathi, P., Matin, S., Khan, M.L., Tripathi, O.P., Deka J., Kumar, P. \& Kushwaha D. (2015). Development of decadal (1985-1995-2005) land use and land cover database for India. Remote Sens., 7, 2401-2430. DOI: $10.3390 / \mathrm{rs} 70302401$.

Running, S.W. (2006). Is global warming causing more, larger wildfires? Science, 313(5789), 927-928. DOI: 10.1126/science. 1130370 .

Secretariat of the convention on biological diversity (2001). Impacts of human- caused fires on biodiversity and ecosystem functioning, and their causes in tropical, temperate and boreal forest biomes. Montreal: SCBD.

Sinha Ray, K.C. \& De U.S. (2003). Climate change in India as evidenced from instrumental records. WMO Bulletin, 2(1), 53-59.

Song, Hark-Soo \& Lee Sang-Hee (2017). Effects of wind and tree density on forest fire patterns in a mixed-tree species forest. Forest Science and Technology, 13(1), 9-16. DOI: 10.1080/21580103.2016.1262793.

Srivastava, R.K. \& Singh D. (2003). Forest fire, haze pollution and climate change. Special issue: Climate change and forestry-Part 1. Indian For., 129, 725-734.

Stephens, S.L. (2005). Forest fire causes and extent on United States Forest Service lands. Int. J. Wildland Fire, 14(3), 213-222. DOI: 10.1071/WF04006.

Swetnam, T.W. \& Betancourt J.L. (1990). Fire southern oscillation relations in the southwestern United-States. Science, 249(4972), 1017-1020. DOI: 10.1126/science.249.4972.1017.

Swetnam, T.W. \& Betancourt J.L. (1998). Mesoscale disturbance and ecological response to decadal climatic variability in the American Southwest. Journal of Climate, 11(12), 3128-3147. DOI: 10.1175/1520-0442(1998)011<3128:MDAER $\mathrm{T}>2.0 . \mathrm{CO} ; 2$. 
Šimanský, V. (2015) Changes in soil structure and soil organic matter due to different severities of fire. Ekológia (Bratislava), 34(3), 226-234. DOI: 10.1515/eko-2015-0022.

Tapper, N.J., Garden, G., Gill, J. \& Fernon J. (1993) The climatology and meteorology of high fire danger in the northern territory. Rangeland Journal, 15(2), 339-351. DOI: 10.1071/RJ9930339.

Tian, X., Shu, L., Zhao, F. \& Wang M. (2012). Forest fire danger changes for southwest China under future scenarios. Scientia Silvae Sinicae, 48, 121-125. http://www.linyekexue.net/EN/10.11707/j.1001-7488.20120120.

Vadrevu, K.P., Badarinath, K.V. \& Anuradha E. (2008). Spatial patterns in vegetation fires in the Indian region. Environ Monit Assess., 147(1-3), 1-13. DOI: 10.1007/s10661-007-0092-6.

Vadrevu, K.P., Ellicott, E., Badarinath, K.V.S. \& Vermote E. (2011). MODIS derived fire characteristics and aerosol optical depth variations during the agricultural residue burning season, north India. Environ. Pollut., 159, 1560-1569. DOI: 10.1016/j.envpol.2011.03.001.

Vadrevu, K.P., Cziszar, I., Ellicott, E., Giglio, L., Badarinath, K.V.S., Vermote, E. \& Justice Ch. (2013). Hotspot analysis of vegetation fires and intensity in the Indian region. IEEE Journal of Selected Topics Applied Earth Observations and Remote Sensing, 6(1), 224-238. DOI: 10.1109/JSTARS.2012.2210699.

Vicente-Serrano, S.M., Begueria, S. \& Lopez-Moreno J.I. (2010). A multi-scalar drought index sensitive to global warming: The Standardized Precipitation Evapotranspiration Index -SPEI. Journal of Climate, 23, 1696-1718. DOI: 10.1175/2009JCLI2909.1.

Vorobyov, Y., (2004) Climate change and disasters in Russia. In Ju.A. Izrael, G. Gruza, S. Semenov, I. Nazarov \& E. Kuasnikova (Eds.), Proceedings of the World Climate Change Conference (pp. 293-298). Moscow: Institute of Global Climate and Ecology.

Wang, W., Zhang, Ch., Allen, J.M., Li, W., Boyer, M.A., Segerson, K. \& Silander J.A. (2016). Analysis and prediction of land use changes related to invasive species and major driving forces in the state of Connecticut. Land, 5(3), 25. DOI: 10.3390/land5030025.

Wells, N., Goddard, S. \& Hayes M.J. (2004) A self-calibrating Palmer Drought Severity Index. Journal of Climate, 17(12), 2335-2351. DOI: 10.1175/1520-0442(2004)017<2335:ASPDSI>2.0.CO;2.

Westerling, A.L., Gershunov, A., Brown, T.J., Cayan, D.R. \& Dettinger M.D. (2003). Climate and wildfire in the western United States. Bulletin of the American Meteorological Society, 84(5), 595-604. DOI: 10.1175/BAMS-84-5-595.

Westerling, A.L. Hidalgo, H.G., Cayan, D.R. \& Swetnam T.W. (2006). Warming and earlier spring increase Western U.S. forest wildfire activity. Science, 313(5789), 940-943. DOI: 10.1126/science.1128834.

Wotton, B.M., Nock, C.A. \& Flannigan M.D. (2010) Forest fire occurrence and climate change in Canada. Int. J. Wildland Fire, 19, 253-271. DOI: 10.1071/WF09002. 